\title{
Sobre pepinos frescos, peras e maçãs
}

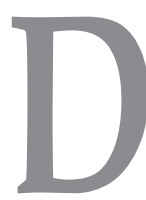

iante das ruínas do Teatro de Dioniso, no pé da Acrópole, pensei no tanto que não sabemos sobre a Grécia Antiga e seu teatro. De tudo o que parece ter sido o Teatro Grego do século $\mathrm{V}$ a.C. restou muito pouco: nomes de escritores mas poucas das muitas peças que escreveram, nomes de filósofos que escreveram sobre o teatro, muitos de seus livros perdidos. E todos homens. Pouco ou nada se sabe sobre o status das mulheres gregas no século de Péricles além de conjecturas produzidas por uma tradição historicamente focada nos feitos dos homens. Salvaram-se fragmentos da escrita de Safo, que se tornou a única escritora conhecida de um tempo que certamente conheceu a escrita de muitas outras a quem se referem seus contemporâneos. O que faziam as mulheres de Atenas enquanto os homens guerreavam, dialogavam, banqueteavam e encenavam suas peças de teatro? Se escreveram, e sabemos que escreveram, como teria sido a sua escrita e sobre o que?

Myrtis teria sido a mestra do tão celebrado Pindauro, poeta tebano, e de Korinna, de quem quase nada se sabe. Os dois discípulos da mestra desconhecida teriam competido num concurso em Tebas em que Korinna saiu vencedora. Atribui-se essa vitória imerecida ao fato de Korinna ter escrito no dialeto da região sobre mitos locais e não, como Pindauro, na língua dórica sobre os mitos panhelênicos. Há a hipótese de que, devido à métrica utilizada, os escritos de algumas mulheres na Grécia Antiga teriam sido destinados ao coro, ou seja, de que foram compostos para serem cantados

1 FONTE: http://www.sikyon.com/sicyon/lysippos/lysip_egpg08.html - Acesso: 2010.

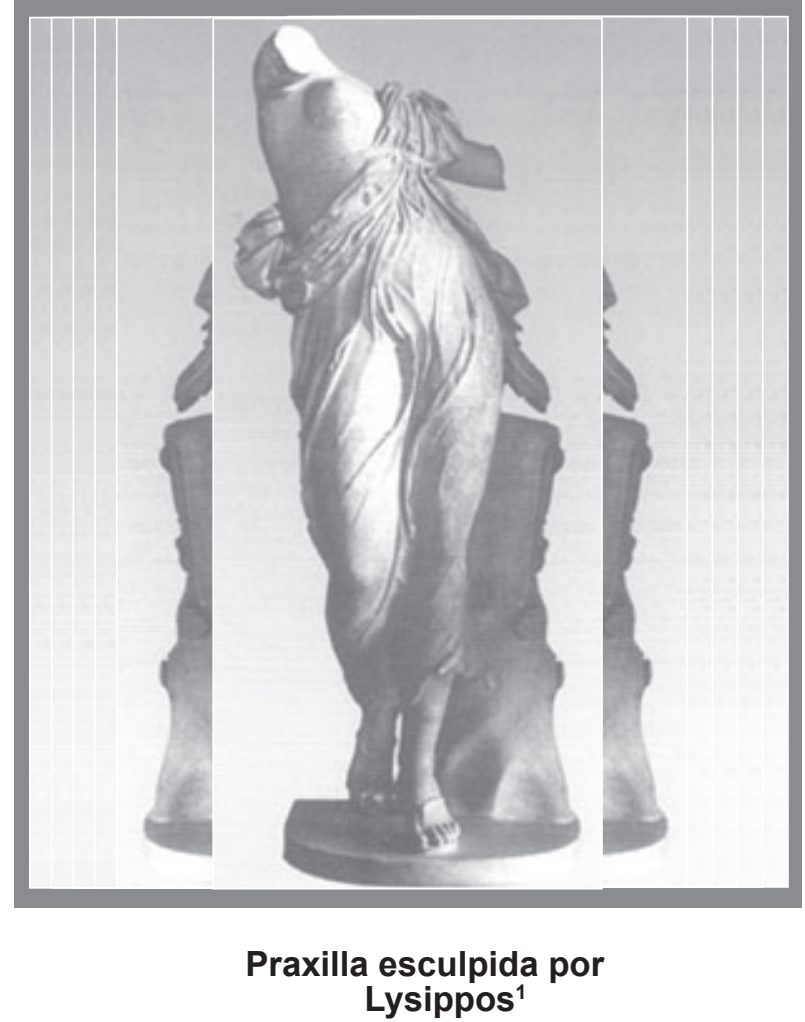

por um grupo de pessoas em festivais religiosos para um público local. Isto é, há indicações de que houve mulheres que escreveram para o teatro grego de então.

Famosa por seus poemas líricos a serem cantados, ou scolia, Praxilla, poeta grega do século $\mathrm{V}$ a.C., também escreveu cantos ditirambos. Conta a história que, por razões políticas, no século VI a.C. os ritos a Dioniso e a prática de coros trágicos e ditirambos foram encorajados em Sicyon, cidade de Praxilla. Citada pela originalidade de sua métrica, sabe-se que, assim como Korinna, Praxilla tinha suas próprias versões dos mitos clássicos. Se para Korinna foi Atena que ensinou Apolo a tocar flauta, para Praxilla a mãe de Dioniso não é Semele, é Afrodite, e não foi Laius que raptou o 
filho de Pelops, foi o próprio Zeus. Apesar de equiparada a grandes poetas seus contemporâneos, não nos restaram vestígios da poesia de Praxilla e, se ela é lembrada por seus contemporâneos, não é devido a sua escrita para o teatro de Sicyon, mas a um único fragmento de sua escrita, insistentemente citado por filósofos e historiadores como exemplo da tolice de uma mulher que se pretende poeta. $\mathrm{O}$ fragmento é de seu hino ou canção em honra de Adonis, intitulado "Adonis no inferno", e constitui parte da resposta de Adonis quando perguntado pelas sombras dos mortos sobre do que ele mais sente falta do mundo dos vivos. Responde Adonis no fragmento de Praxilla:

Finest of all the things I have left is the light of the sun, Next to that the brilliant stars and the face of the moon, Cucumbers in their season, too, and apples and pears. (tradução de Bernard Knox)

O melhor de tudo o que deixei é a luz do sol, Depois é o brilho das estrelas e a face da lua, Pepinos frescos também, e maçãs e peras.

(minha tradução)

Com a menção aos pepinos frescos foi-se a reputação de Praxilla. Afinal, não se mistura pepinos com astros do firmamento, em poesia ou em pensamento. Não combina com um deus desejar coisas terrenas, tão triviais, tão pequenas. Praxilla tornou-se provérbio, sinônimo de tolice (que é prima-irmã da burrice), incompetência e mau gosto. Praxilla virou piada e assim ela é lembrada.

Não sei se o mitológico Adonis pensaria em pepinos, peras e maçãs quando de sua passagem pelo inferno, mas o Adonis de Praxilla, esse pensou, ou ELA pensou nos legumes e frutas frescas que talvez tenha plantado nessa ou naquela estação, e colhido e preparado pra servir na refeição. No universo de Praxilla os astros e os legumes se misturam sim, num cotidiano, simples e mundano, de que é feito a história, suas lendas, seus heróis, toda uma tradição, e em que ela, Praxilla, cuida da plantação - de pepinos e poemas, verduras e versos frescos, peras e peças para o teatro, música e maçãs...

Quem já não esteve no inferno e, quando lá, não sentiu algum desejo? Qual foi o seu? Eu já estive no porão mais de uma vez e desejei... Não vou dizer e me trair qual Praxilla ou outra de nós qualquer que, ao se dizer, se diz mulher.

O teatro da antiga Sicyon de Praxilla, cujas ruínas podem ser hoje visitadas, era um dos maiores teatros da Grécia Antiga. Segundo a lenda, foi esse teatro que testemunhou o nascimento da tragédia. Nele havia uma estatua de Praxilla esculpida por Lysippos. Não sei se ainda está lá, ou onde estará, sei que há uma cópia em mármore da escultura original no acervo do Museu de Berlim em que a cabeça de Praxilla já se encontra destruída. A Praxilla exibida em Berlim está decapitada, assim como foi a poeta pela história da literatura e do teatro. Restam seu nome e seu corpo mutilado; seus poemas, seu teatro, se perderam, como todos os seus hinos, só ficaram seus pepinos.

No oráculo de Delfo eu pressinto a minha sina: jamais esquecer Atenas, seus teatros em ruínas, seus templos, os deuses de então, destronados, destruídos pelo tempo, pela civilização, as águas do Mar Egeu, sua cor azul marinho e, claro, as azeitonas frescas no caminho.

Atenas, 12 de outubro de 2010 Lucia V. Sander 